\title{
A disparate trace element metabolism in zebu (Bos indicus) and crossbred (Bos indicus $\times$ Bos taurus) cattle in response to a copper-deficient diet
}

Dermauw, Veronique ; De Cuyper, A ; Duchateau, L ; Waseyehon, A ; Dierenfeld, E ; Clauss, Marcus ; Peters, I R ; Du Laing, G ; Janssens, G P J

\begin{abstract}
Copper deficiency is a commonly diagnosed problem in cattle around the globe. In Jimma, Ethiopia, 8 zebu (Bos indicus) and 8 zebu $\times$ Holstein Friesian cross (Bos taurus $\times$ Bos indicus) heifers were used in an 11-wk study to investigate breed type differences and effects of $\mathrm{Cu}$ deficiency on concentrations of trace elements in plasma and edible tissues as well as mRNA expression of Cu-related genes. Heifers were fed a grass diet $(6.4 \pm 0.2[\mathrm{SEM}] \mathrm{mg} \mathrm{Cu} / \mathrm{kg} \mathrm{DM})$ supplemented with $1 \mathrm{mg} \mathrm{Mo} / \mathrm{kg} \mathrm{DM}$ in wk 1 to 4 and $2 \mathrm{mg} \mathrm{Mo} / \mathrm{kg} \mathrm{DM}$ in wk 5 to 11, with blood samples collected every 2 wk and tissue collection postmortem. Plasma, liver, kidney, and semitendinosus and cardiac muscle were analyzed for $\mathrm{Zn}, \mathrm{Cu}, \mathrm{Fe}$, Se, Mo, Co, and Mn. Expression of mRNA Cu-related genes was measured in aorta (lysyl oxidase [LOX]), liver ( $\mathrm{Cu}$ transporting -polypeptide [Atp7b], $\mathrm{Cu}$ chaperone for superoxide dismutase [CCS], cytochrome c oxidase assembly homolog 17 [Cox17], $\mathrm{Cu}$ transporter 1 homolog [Ctr1], and superoxide dismutase 1 [Sod1]), and duodenum (diamine oxidase [DAO] and metallo-thionein-1A [Mt1a]) as well as the Se-related glutathione peroxidase 1 (Gpx1). Zebu cattle maintained initial plasma $\mathrm{Cu}$ concentrations just below the threshold value for deficiency, whereas crossbred cattle gradually became severely $\mathrm{Cu}$ deficient over time $(\mathrm{P}<0.001)$. In contrast, plasma $\mathrm{Zn}$ and $\mathrm{Co}$ were greater in zebu cattle at the onset of the trial but became similar to crossbred cattle towards the end of the trial $(\mathrm{P}<0.001)$. Liver $\mathrm{Cu}(\mathrm{P}=0.002)$ and Fe $(\mathrm{P}$ 0.001), kidney Se $(\mathrm{P}<0.001)$, and kidney and cardiac muscle Co $(\mathrm{P} \quad 0.001)$ concentrations were greater in zebu than in crossbred cattle. Increased hepatic mRNA expression of the Cu regulatory genes Atp7b, Ctr1 $(\mathrm{P}=0.02)$, CCS $(\mathrm{P}=0.03)$, and Cox17 $(\mathrm{P}=0.009)$ and Cu-related Sod1 $(\mathrm{P}=0.001)$ as well as the Se-related Gpx1 ( $\mathrm{P}$ 0.001) were greater in zebu than in crossbred cattle. However, duodenal mRNA expression of DAO $(\mathrm{P}=0.8)$ and Mt1a $(\mathrm{P}=0.2)$ and aortic expression of LOX $(\mathrm{P}=0.8)$ were not different. Both the differences in $\mathrm{Cu}$ status indices (plasma and liver concentrations) and hepatic mRNA expression of $\mathrm{Cu}$ regulatory genes point to the possibility of a more efficient use of dietary $\mathrm{Cu}$ in B. indicus as compared to B. taurus $\times$ B. indicus cattle resulting in greater sensitivity to $\mathrm{Cu}$ deficiency in B. taurus crossbred cattle.
\end{abstract}

DOI: https://doi.org/10.2527/jas.2013-6979

Posted at the Zurich Open Repository and Archive, University of Zurich

ZORA URL: https://doi.org/10.5167/uzh-97048

Journal Article

Published Version

Originally published at:

Dermauw, Veronique; De Cuyper, A; Duchateau, L; Waseyehon, A; Dierenfeld, E; Clauss, Marcus; Peters, I R; Du Laing, G; Janssens, G P J (2014). A disparate trace element metabolism in zebu (Bos indicus) 
and crossbred (Bos indicus $\times$ Bos taurus) cattle in response to a copper-deficient diet. Journal of Animal Science, 92(7):3007-3017.

DOI: https://doi.org/10.2527/jas.2013-6979 


\title{
A disparate trace element metabolism in zebu (Bos indicus) and crossbred (Bos indicus $\times$ Bos taurus) cattle in response to a copper-deficient $\operatorname{diet}^{1}$
}

\author{
V. Dermauw, ${ }^{* 2,3}$ A. De Cuyper,* L. Duchateau, $\dagger$ A. Waseyehon, \\ E. Dierenfeld,§ M. Clauss,\# I. R. Peters, || G. Du Laing, $\mid$ and G. P. J. Janssens*
}

\begin{abstract}
*Laboratory of Animal Nutrition, Faculty of Veterinary Medicine, Ghent
University, Heidestraat 19, B-9820 Merelbeke, Belgium; $†$ Department of Comparative Physiology

and Biometrics, Faculty of Veterinary Medicine, Ghent University, Salisburylaan 133, B-9820 Merelbeke, Belgium; ¥Department of Animal Science, College of Agriculture and Veterinary Medicine of Jimma University, P.O. Box 307, Jimma, Ethiopia; §Zootrition Consulting, LLC, 4736 Gatesbury Drive, St. Louis, MO; \#Clinic for Zoo Animals, Exotic Pets and Wildlife, Vetsuisse Faculty, University of Zurich, Winterthurerstrasse 260, 8057 Zurich, Switzerland; ||TDDS, The Innovation Centre, University of Exeter, Exeter, Devon, EX4 4RN, UK; and $\mid$ Laboratory of Analytical Chemistry and Applied Ecochemistry, Ghent University, Faculty of Bioscience Engineering, Coupure Links 653, B-9000 Ghent, Belgium
\end{abstract}

ABSTRACT: Copper deficiency is a commonly diagnosed problem in cattle around the globe. In Jimma, Ethiopia, 8 zebu (Bos indicus) and 8 zebu $\times$ Holstein Friesian cross (Bos taurus $\times$ Bos indicus) heifers were used in an 11-wk study to investigate breed type differences and effects of $\mathrm{Cu}$ deficiency on concentrations of trace elements in plasma and edible tissues as well as mRNA expression of $\mathrm{Cu}$-related genes. Heifers were fed a grass diet $(6.4 \pm 0.2$ [SEM] $\mathrm{mg} \mathrm{Cu} / \mathrm{kg} \mathrm{DM})$ supplemented with $1 \mathrm{mg} \mathrm{Mo} / \mathrm{kg}$ DM in wk 1 to 4 and $2 \mathrm{mg} \mathrm{Mo} /$ $\mathrm{kg}$ DM in wk 5 to 11 , with blood samples collected every $2 \mathrm{wk}$ and tissue collection postmortem. Plasma, liver, kidney, and semitendinosus and cardiac muscle were analyzed for $\mathrm{Zn}, \mathrm{Cu}, \mathrm{Fe}$, Se, $\mathrm{Mo}, \mathrm{Co}$, and $\mathrm{Mn}$. Expression of mRNA Cu-related genes was measured in aorta (lysyl oxidase $[L O X])$, liver $(\mathrm{Cu}$ transporting $\beta$-polypeptide [Atp $7 b], \mathrm{Cu}$ chaperone for superoxide dismutase [CCS], cytochrome c oxidase assembly homolog 17 [Cox17], $\mathrm{Cu}$ transporter 1 homolog [Ctrl], and superoxide dismutase $1[\operatorname{Sod} 1]$ ), and duodenum (diamine oxidase [DAO] and metallo-thionein-1A $[M t 1 a])$ as well as the Se-related glutathione peroxidase 1 (Gpxl). Zebu cattle maintained initial plasma $\mathrm{Cu}$ concentrations just below the threshold value for deficiency, whereas crossbred cattle gradually became severely $\mathrm{Cu}$ deficient over time $(P<0.001)$. In contrast, plasma $\mathrm{Zn}$ and Co were greater in zebu cattle at the onset of the trial but became similar to crossbred cattle towards the end of the trial $(P<0.001)$. Liver $\mathrm{Cu}$ $(P=0.002)$ and $\mathrm{Fe}(P \leq 0.001)$, kidney Se $(P<0.001)$, and kidney and cardiac muscle Co $(P \leq 0.001)$ concentrations were greater in zebu than in crossbred cattle. Increased hepatic mRNA expression of the $\mathrm{Cu}$ regulatory genes Atp $7 b, C t r 1(P=0.02), C C S(P=0.03)$, and $\operatorname{Cox} 17(P=0.009)$ and Cu-related $\operatorname{Sodl}(P=0.001)$ as well as the Se-related $\operatorname{Gpxl}(P \leq 0.001)$ were greater in zebu than in crossbred cattle. However, duodenal mRNA expression of DAO $(P=0.8)$ and Mt1a $(P=0.2)$ and aortic expression of $\operatorname{LOX}(P=0.8)$ were not different. Both the differences in $\mathrm{Cu}$ status indices (plasma and liver concentrations) and hepatic mRNA expression of $\mathrm{Cu}$ regulatory genes point to the possibility of a more efficient use of dietary $\mathrm{Cu}$ in $B$. indicus as compared to $B$. taurus $\times B$. indicus cattle resulting in greater sensitivity to $\mathrm{Cu}$ deficiency in B. taurus crossbred cattle.

Key words: Bos indicus, cattle, copper, deficiency, trace element, zebu

(C) 2014 American Society of Animal Science. All rights reserved.

J. Anim. Sci. 2014.92:3007-3017

doi:10.2527/jas2013-6979

\footnotetext{
${ }^{1}$ This research was performed within the doctoral research project of Veronique Dermauw, funded by the Agency for the Promotion of Innovation through Science in Flanders (IWT-Vlaanderen), grant no. 093348. We would like to acknowledge the IUC-JU program of VLIRUOS for logistic support and the farmers of JUCAVM dairy farm for help during feeding and sampling. Furthermore, we would like to thank Ria Van Hulle for mineral analyses and Herman De Rycke for feed analyses.
}

\footnotetext{
${ }^{2}$ Current affiliation: Clinical and Experimental Endocrinology, KU Leuven, Belgium

${ }^{3}$ Corresponding author: Veronique.Dermauw@ugent.be

Received July 31, 2013.

Accepted April 12, 2014.
} 


\section{INTRODUCTION}

The dietary micromineral supply for cattle is often low in tropical countries (McDowell and Arthington, 2005). Mineral imbalances in the soil and consequently in the plants growing on this soil often aggravate this situation (Haque et al., 1993). In Ethiopia, copper deficiency is a frequent problem when grazing on pastures, as low levels of $\mathrm{Cu}$ are accompanied by high levels of Mo and S and very high levels of Fe (Roeder, 1980; Faye and Grillet, 1984; Faye et al., 1991; Dermauw et al., 2013a). Consequently, deficiencies of $\mathrm{Cu}$ are to be expected in cattle in these regions.

Zebu cattle (Bos indicus) are the most common type of cattle in Ethiopia and renowned for their robustness under tough conditions (Edea et al., 2013). Moreover, they seem to have adapted to their environment very well, with reports indicating an ability to cope with dietary antagonists, such as tannins (Yisehak et al., 2012). However, because of their low production capacity, crossbreeding these $B$. indicus cattle with Bos taurus types is becoming popular (Fekadu et al., 2011). Within B. taurus cattle, breed-related sensitivity to $\mathrm{Cu}$ deficiency has been documented, with the Simmental breed reported as being most vulnerable (Mullis et al., 2003; Ward et al., 1995). Several studies suggest that there may be a difference between $B$. taurus-influenced and $B$. indicus cattle in their ability to cope with an inadequate $\mathrm{Cu}$ supply. Frequently, no signs of clinical copper deficiency are seen in studies with zebu cattle despite severely inadequate $\mathrm{Cu}$ supply based on recommended levels for B. taurus cattle (Roeder, 1980; Faye et al., 1991; Dermauw et al., 2013b). Other studies suggest that there might be a difference in response to the same diet between the local zebu cattle and B. taurus crossbred cattle (Friot, 1973; Damir et al., 1988).

As we hypothesized that $B$. indicus may have adapted to a low $\mathrm{Cu}$ intake, hence optimizing the use of $\mathrm{Cu}$ in their metabolism, our aim was to evaluate the effect of a $\mathrm{Cu}$-deficient diet on concentrations of $\mathrm{Cu}$ and other trace elements in plasma and edible tissues as well as mRNA expression of $\mathrm{Cu}$-related genes in $B$. indicus and B. taurus $\times B$. indicus cattle.

\section{MATERIALS AND METHODS}

\section{Animal Care and Experimental Design}

Sixteen B. indicus (Abyssinian Highland zebu; $n=$ 8 ) heifers and B. taurus $\times$ B. indicus crossbred (Holstein Friesian $\times$ Abyssinian Highland zebu; $n=8)$ heifers with an average age of $1 \mathrm{yr}$ and $6 \mathrm{mo}(\mathrm{SD}=0.4 \mathrm{yr})$ were purchased and housed at the dairy farm of the Jimma University Campus of Agriculture and Veterinary Medicine, Ethiopia. In the surrounding area, bovine $\mathrm{Cu}$
Table 1. Chemical composition of basal grass diet samples $(n=11)$

\begin{tabular}{lcc}
\hline \hline Component & Mean & SEM \\
\hline $\mathrm{CP}, \% \mathrm{DM}$ & 11.5 & 0.37 \\
$\mathrm{ADF}, \% \mathrm{DM}$ & 35.4 & 0.81 \\
$\mathrm{NDF}, \% \mathrm{DM}$ & 67.7 & 0.59 \\
$\mathrm{~S}, \mathrm{~g} / \mathrm{kg} \mathrm{DM}$ & 2.4 & 0.12 \\
$\mathrm{Fe}, \mathrm{mg} / \mathrm{kg} \mathrm{DM}$ & 250 & 27.9 \\
$\mathrm{Mn}, \mathrm{mg} / \mathrm{kg} \mathrm{DM}$ & 102 & 15.9 \\
$\mathrm{Zn}, \mathrm{mg} / \mathrm{kg} \mathrm{DM}$ & 64 & 3.7 \\
$\mathrm{Cu}, \mathrm{mg} / \mathrm{kg} \mathrm{DM}$ & 6.4 & 0.23 \\
$\mathrm{Co}, \mathrm{mg} / \mathrm{kg} \mathrm{DM}$ & 0.22 & 0.016 \\
$\mathrm{Mo}, \mathrm{mg} / \mathrm{kg} \mathrm{DM}$ & & 0.41 \\
$\mathrm{Se}, \mathrm{mg} / \mathrm{kg} \mathrm{DM}$ & 2.1 & 0.026 \\
\hline
\end{tabular}

${ }^{1}$ Supplemented with $1.0 \mathrm{mg} \mathrm{Mo} / \mathrm{kg}$ DM from wk 1 to 4 and with $2.0 \mathrm{mg}$ $\mathrm{Mo} / \mathrm{kg} \mathrm{DM}$ from wk 5 to 11 , as $\mathrm{NaMoO}_{4}$.

deficiency was seen on multiple occasions and Se deficiency was suspected based on tissue levels below threshold values for B. taurus cattle (Dermauw et al., 2013a,b).

All animals were individually housed and fed with a forage-only diet, consisting of mature local grasses, freshly harvested and chopped $(20 \mathrm{~cm})$, during $11 \mathrm{wk}$. This diet contained $6.4 \pm 0.2(\mathrm{SEM}) \mathrm{mg} \mathrm{Cu} / \mathrm{kg} \mathrm{DM}, 2.1 \pm 0.4 \mathrm{mg}$ $\mathrm{Mo} / \mathrm{kg} \mathrm{DM}$, and $2.4 \pm 0.12 \mathrm{~g} \mathrm{~S} / \mathrm{kg}$ DM (Table 1). Daily amounts of grasses provided were set to provide a DM intake of $2 \%$ of BW (McDowell, 1996). Refusals were weighed and subtracted from the offered amount of grass daily. To induce $\mathrm{Cu}$ deficiency, $\mathrm{Mo}$ (as $\mathrm{NaMoO}_{4}$; SigmaAldrich, St. Louis, MO) was supplemented at $1 \mathrm{mg} / \mathrm{kg}$ DM during wk 1 to 4 and raised to $2 \mathrm{mg} / \mathrm{kg}$ DM from wk 5 to 11 . The supplements were mixed in a spoon $(15 \mathrm{~mL})$ of molasses and top-dressed on the grass diet.

Every $2 \mathrm{wk}$, the BCS of heifers was noted. The BCS of crossed heifers was evaluated on a scale of 1 to 5 for B. taurus dairy cattle (Wildman et al., 1982), whereas for zebu heifers, the BCS was evaluated using the $B$. indicus scale of 1 to 9 (Nicholson and Butterworth, 1986). Zebu BCS subsequently were recalculated to a scale of 1 to 5 , for comparison purposes.

\section{Samples and Storage}

Representative feed samples were collected 3 times a week and stored at $-40^{\circ} \mathrm{C}$. Afterward, samples were pooled per week, oven dried at $65^{\circ} \mathrm{C}$ until constant weight, and subsequently ground through a 2-mm sieve. Every 2 wk, $9 \mathrm{~mL}$ blood was collected from all animals by jugular venipuncture using 18 gauge needles (450069) and 2 sodium heparin tubes (455051; both Vacuette; Greiner Labortechnik, Kremsmunster, Austria). At wk 11, all animals were brought to a local slaughterhouse and slaughtered. Approximately $50 \mathrm{~g}$ of liver (caudal lobe), kidney (cranial part of left kidney), and cardiac (heart apex) and 
semitendinosus muscle were collected to determine trace element concentrations in these tissues. Additionally, samples of aorta, small intestine, and liver were collected to determine mRNA expression of $\mathrm{Cu}$ transporters and $\mathrm{Cu}$-related enzymes.

Plasma was obtained through centrifugation at 1,500 $\times$ $g$ for $10 \mathrm{~min}$ at $25^{\circ} \mathrm{C}$ and was stored at $-20^{\circ} \mathrm{C}$ until further analysis. Tissue samples for mineral analyses were initially frozen at $-40^{\circ} \mathrm{C}$, afterward oven dried at $65^{\circ} \mathrm{C}$ until constant weight, and ground through a $2-\mathrm{mm}$ sieve. Tissue samples for mRNA analyses were immediately immersed in $10 \mathrm{~mL}$ RNAlater (Sigma-Aldrich) and frozen at $-40^{\circ} \mathrm{C}$.

\section{Analytical Procedures}

Grass samples were analyzed for CP (method 990.03; AOAC, 2000), ADF (method 973.18; AOAC, 2000), and NDF (Van Soest et al., 1991). Plasma, grasses, and tissue samples for mineral analysis were prepared through microwave digestion with $10 \mathrm{~mL} \mathrm{HNO}_{3}$ (ultrapure analytical grade for trace element analysis) in open vessels followed by filtration through syringe filters (Chromafil RC-45/25, regenerated cellulose, pore size $0.45 \mu \mathrm{m}$; Macherey-Nagel, Düren, Germany). All samples were analyzed for $\mathrm{Zn}, \mathrm{Cu}, \mathrm{Fe}$, Se, Mo, Co, and Mn concentrations and grass samples additionally for $\mathrm{S}$ through inductively coupled plasma optical emission spectrometry (Vista MPX radial; Varian, Palo Alto, CA) and inductively coupled plasma mass spectrometry (Elan DRC-e; PerkinElmer, Sunnyvale, CA). All glassware and microwave vessels were prerinsed with diluted $\mathrm{HNO}_{3}$. A quality control program was used throughout mineral analyses. Recovery rates from sampled matrices, spiked with 2 concentrations of the studied trace elements (in the range of the determined concentrations), were measured. Average recovery was $98 \%$, with a range between $82 \%$ (Zn in plasma) and 109\% (Mo in kidney). Lower detection limits in acid digest were determined as $0.35 \mu \mathrm{g} / \mathrm{L}$ for $\mathrm{Mn}, 0.25 \mu \mathrm{g} / \mathrm{L}$ for $\mathrm{Cu}, 0.33 \mu \mathrm{g} / \mathrm{L}$ for $\mathrm{Mo}, 0.13 \mu \mathrm{g} / \mathrm{L}$ for $\mathrm{Se}$, $21.4 \mu \mathrm{g} / \mathrm{L}$ for Fe, $16.4 \mu \mathrm{g} / \mathrm{L}$ for $\mathrm{Zn}$, and $0.14 \mu \mathrm{g} / \mathrm{L}$ for Co. Control standards were analyzed after every 20 samples or less followed by a recalibration. The obtained results of each sample batch were only accepted if the deviation of each concentration measured in the control standards from the targeted concentration was less than 5\%. All analytical results were blank corrected.

\section{Quantitative Real Time Reverse Transcription PCR}

Total RNA was isolated from tissue samples using either the RNeasy Mini Kit (intestine and liver) or RNeasy Fibrous Tissue Mini Kit (aorta; Qiagen Ltd., Manchester, $\mathrm{UK}$ ). Tissue samples (mean $=48 \mathrm{mg}$ and range $=35$ to $60 \mathrm{mg}$ ) were homogenized in a TissueLyser (Qiagen
Ltd.) using $500 \mu \mathrm{L}$ of lysis buffer from the extraction kits and a 5-mm steel ball bearing in a 2-mL Safe-Lock tube (Eppendorf, Stevenage, UK), with 3 cycles of shaking at 20 $\mathrm{Hz}$ for $2 \mathrm{~min}$. Lysates were then processed as per the manufacturer's instructions, including the optional on-column deoxyribonuclease (DNase) digestion step. The RNA was eluted in $2 \times 50 \mu \mathrm{L}$ of nuclease-free water. Further DNase digestion of the RNA solution was performed using RQ1 RNase-Free DNase (Promega Ltd., Southampton, UK) as per the manufacturer's instructions with the sample incubated for $30 \mathrm{~min}$ at room temperature. To remove the DNase and reaction buffer from the purified RNA, it was passed through the RNeasy Mini Kit using the RNA cleanup protocol and was eluted in $2 \mathrm{x} 40 \mu \mathrm{L}$ of elution buffer (10 $\mathrm{m} M$ Tris $\mathrm{HCl}, \mathrm{pH}$ 8.4). The RNA concentration in the eluate was measured using the Qubit RNA Assay Kit (Invitrogen, Paisley, Scotland).

Primers and probes (Table 2) were designed using Primer 3 (Rozen and Skaletsky, 2000; http://frodo. wi.mit.edu) and M-Fold (SantaLucia, 1998; available at http://mfold.rna.albany.edu/?q=mfold) using the bovinespecific GenBank sequences for the potential housekeeper genes: $\beta$-2-microglobulin (B2M; NM 173893), glyceraldehyde-3-phosphate dehydrogenase (GAPDH; NM 001034034), hypoxanthine phosphoribosyl-transferase 1 (HPRT1; NM 001034035), ribosomal protein S8 (RPS8; NM 001025317), succinate dehydrogenase complex, subunit A (SDHA; NM 174178), and tyrosine 3-monooxygenase/tryptophan 5-monooxygenase activation protein, zeta polypeptide (YWAZ; XM 001788370) as well as adenosine triphosphatase, copper transporting, $\beta$ polypeptide (Atp7b; XM 002691794), copper chaperone for superoxide dismutase (CCS; NM 001046187), cytochrome c oxidase assembly homolog 17 (Cox17; XM 002684734), copper transport 1 homolog (Ctr1; NM 001100381), diamine oxidase (DAO; NM 001034361), glutathione peroxidase 1 (Gpxl; NM 174076), lysyl oxidase ( $L O X$; NM 173932), metallothionein-1A (Mt1a; NM 001040492), and superoxide dismutase 1 (Sod1; NM 174615) as described previously (Peters et al., 2004). Primer specificity was tested using the Primer BLAST algorithm (www.ncbi.nlm.nih.gov).

Synthesis of cDNA was performed with $500 \mathrm{ng}$ of random hexamers using the ImProm-II Reverse Transcription (RT) System (Promega Corp., Madison, WI) using 600 to $1,000 \mathrm{ng}$ (liver and intestine) or $200 \mathrm{ng}$ (aorta) of total RNA in a final volume of $40 \mu \mathrm{L}$. All reactions were prepared according to the manufacturer's instructions giving a final magnesium chloride concentration of $3 \mathrm{~m} M$.

Reverse transcription was performed in a PTC-200 DNA engine (Bio-Rad Laboratories Inc., Hercules, CA). Duplicate RT reactions were performed for each RNA sample. All cDNA were diluted to a final volume of 
Table 2. Real-time RT-PCR primers of $\mathrm{Cu}$ regulatory genes examined in aorta, duodenum, and liver of zebu (Bos indicus) and crossbreed (Bos indicus $\times$ Bos taurus) heifers on a $\mathrm{Cu}$-deficient diet

\begin{tabular}{|c|c|c|c|c|c|c|}
\hline Gene & Assay & Forward primer & Reverse primer & $\mathrm{PS},{ }^{1} \mathrm{bp}$ & $\mathrm{E}^{2}$ & $\mathrm{PMT}^{3}$ \\
\hline \multirow[t]{2}{*}{$\overline{A t p 7 b}$} & Control & TAGAAGGCAAGATCGGGAAA & CTGGGGAGACGAGAGAAGG & 435 & & \\
\hline & $\mathrm{qPCR}^{4}$ & TAGAAGGCAAGATCGGGAAA & ATGTGGTCCCTGAGGTCTTG & 121 & 94.9 & 87.0 \\
\hline \multirow[t]{2}{*}{$B 2 M$} & Control & GTTCCATCCACCCCAGATT & TTACAGGTCTCGATCCCACTT & 211 & & \\
\hline & qPCR & GTTCACTCCCAACAGCAAGG & ACTATCCGGGGTTGTTCCA & 72 & 98.7 & 82.0 \\
\hline \multirow[t]{2}{*}{$C C S$} & Control & CTGTGGGGACCACTTTAACC & AGGCCATCACAGGAGCAG & 388 & & \\
\hline & qPCR & CAGGATCACAGGAAACTCAGG & GCTTGGGGTTCTGGAAGAG & 80 & 96.1 & 85.5 \\
\hline \multirow[t]{2}{*}{ Ctr1 } & Control & TGGGGATGAACATGGATATG & AATGGCAATGCTCTGTGATG & 549 & & \\
\hline & qPCR & CCCAACCACTTCATCTGACC & AAAGCTCCAGCCATTTCTCC & 138 & 99.3 & 83.0 \\
\hline \multirow[t]{2}{*}{$D A O$} & Control & GCACTGTACGGAGGACACAC & CCGTTGGGGTAGAAGATGAA & 350 & & \\
\hline & qPCR & ACGCCCTCCACTACTACGAC & GGGCATCTCGAAGAGACAGA & 71 & 96.7 & 86.0 \\
\hline$G A P D H$ & Control & ACCAGGGCTGCTTTTAATTCT & GGTCATAAGTCCCTCCACGA & 474 & & \\
\hline \multirow[t]{2}{*}{$H P R T 1$} & Control & CCAGTCAACAGGCGACATAA & GGCTCGTAGTGCAAATGAAGA & 527 & & \\
\hline & qPCR & GCGAAACTGGAAAAGCAAAA & GCCACAGAACAAGAACATTGG & 116 & 93.0 & 82.0 \\
\hline \multirow[t]{2}{*}{$L O X$} & Control & ATACGGCACCGGCTACTTC & ССCTCAGCCACTCTCCTCT & 348 & & \\
\hline & qPCR & CCCCAGAGAGTGAAAAACCA & TGGCATCAAGCAGGTCATAG & 139 & 95.7 & 84.0 \\
\hline \multirow[t]{2}{*}{ Mt1a } & Control & CTGCTTTGCCACTTGTTCTG & GCACCAGGTCAGATTGTATGAA & 342 & & \\
\hline & qPCR & CTGATGTCGGGGAGAACCT & AAGGTAATGTAGCACCAGGTCAG & 101 & 98.2 & 79.0 \\
\hline \multirow[t]{2}{*}{ RPS8 } & Control & CATCTCTCGGGACAACTGG & TTCGCGTTCTTTTTCCTCTC & 464 & & \\
\hline & qPCR & CATCTCTCGGGACAACTGG & GCGTCCCAGCTCATACTTTC & 88 & 96.7 & 86.0 \\
\hline \multirow[t]{2}{*}{ SDHA } & Control & TGCAGACCCGGAGATAAAGT & CGTACTCGTCAACCCTCTCC & 391 & & \\
\hline & qPCR & TAAACCAAATGCTGGGGAAG & CTGCATGTTGAGTCGCAGTT & 97 & 95.1 & 81.5 \\
\hline Sodl & Control & GCAAGGCACCATCCACTT & CACCTCTGCCCAAGTCATCT & 341 & & \\
\hline
\end{tabular}

${ }^{1} \mathrm{PS}=$ product size.

${ }^{2} \mathrm{E}=$ efficiency.

${ }^{3} \mathrm{PMT}=$ product melting temperature.

${ }^{4} \mathrm{qPCR}=$ quantitative PCR.

$200 \mu \mathrm{L}$ (1:5 dilution) using EB Buffer (10 m $M$ Tris-HCl, $\mathrm{pH}$ 8.4; Qiagen Ltd.) and then stored at $-20^{\circ} \mathrm{C}$ for future use. Nontemplate controls were performed by addition of nuclease-free water in place of RNA.

Quantitative PCR (qPCR) was performed using GoTaq Colourless Master Mix (Promega Corp., Madison, WI). Gene specific amplification was performed using $0.2 \mu M$ of each primer, SYBR Green 1 (1:100,000 final concentration; Invitrogen), ROX (1:5,000; Invitrogen), and $5 \mu \mathrm{L}$ of diluted cDNA in a final volume of $25 \mu \mathrm{L}$. Magnesium chloride concentrations were adjusted to 4.5 $\mathrm{m} M$ in the final reaction by addition of $50 \mathrm{mM} \mathrm{MgCl} 2$.

Sample incubations were performed in an MxPro 3005P (Agilent Technologies, Wokingham, Berkshire, $\mathrm{UK}$ ) at $95^{\circ} \mathrm{C}$ for $2 \mathrm{~min}$ and then 45 cycles of $95^{\circ} \mathrm{C}$ for 10 $\mathrm{s}$ and $60^{\circ} \mathrm{C}$ for $30 \mathrm{~s}$ during which the fluorescence data were collected. Threshold values $(\mathbf{C t})$ for the samples were calculated using the MxPro qPCR software (version 4.1; Agilent Technologies) using the multiple experiment analyzer with run-to-run variations in $\mathrm{Ct}$ normalized using a positive control of known copy number and ROX as a passive reference dye.

The absence of genomic contamination of the RNA samples was confirmed before the RT reactions and none of the samples showed evidence of amplifiable genomic DNA with the SDHA qPCR assay. One qPCR reaction was run for each RT repeat resulting in $2 \mathrm{Ct}$ values for each RNA sample.

To determine the most appropriate housekeeper genes for the study, all 7 potential genes were quantified in 6 cDNA samples from each tissue type. A mean Ct value was calculated for each sample using the 2 measured $\mathrm{Ct}$ values for each sample for each of the potential housekeeper genes. The mean $\mathrm{Ct}$ value was converted to a relative copy number 
value using the $\mathrm{E}^{\Delta \mathrm{Ct}}$ method ( $\mathrm{E}$ = reaction efficiency as determined from a standard curve) with $\Delta \mathrm{Ct}$ values calculated relative to the sample with the largest $\mathrm{Ct}$ (fewest gene copies). The geNorm VBA applet (Vandesompele et al.,2002; available at http://medgen.ugent.be/\%7Ejvdesomp/genorm/) for Microsoft Excel (Microsoft Corp., Redmond, WA) was used to determine the most stable genes from the set of tested genes. The 3 most stable housekeeper genes for the aorta samples were $B 2 M, H P R T 1$, and $S D H A$; for the intestine were $G A P D H, S D H A$, and $Y W A Z$; and for the liver were $B 2 M, H P R T 1$, and SDHA. The 3 selected housekeeper genes were then quantified in the remaining samples and these genes were then used to normalize the results for the other genes quantified.

A relative copy number was calculated for each sample using the qBase applet for Microsoft Excel (http:// medgen.ugent.be/qbase) using the 3 housekeeper genes to normalize the results, using the methods described by Vandesompele et al. (2002). The sample with the fewest gene copies (latest $\mathrm{Ct}$ value) is given a relative copy number of 1 and all other samples are given values relative to this sample. This relative copy number result was used for all comparisons involving mRNA expression.

To assess reaction efficiency, a set of primers was designed for each gene target to amplify a larger fragment, which included the portion amplified by the qPCR assay. These assays were tested against a cDNA obtained from RNA extracted from each of the tissues. Products were separated by $2 \%$ agarose gel electrophoresis, purified by NucleoSpin Extract II kit (MachereyNagel), and then quantified using the Qubit dsDNA BR Assay (Invitrogen). The number of copies per microliter of purified product was calculated and then a 1:10 dilution series from $10^{7}$ to 1 copy per qPCR was analyzed in triplicate using the qPCR assay and the reaction efficiency calculated using the MxPro software.

\section{Statistical Analyses}

All statistical procedures were performed using the mixed model (SAS Inst. Inc., Cary, NC). For weight, $\mathrm{BCS}$, and plasma mineral concentrations, the model included sampling week as a continuous fixed effect, breed type as categorical fixed effect, and their interaction. Heifer was considered as the experimental unit and was inserted as a random effect. For tissue mineral concentrations, the model included tissue and breed type as a categorical fixed effect and their interaction. Again, heifer was incorporated as a random effect. To compare mRNA expression and performance data, a fixed effects model was used with type included as categorical fixed effect. Associations between trace element storage and mRNA expression were evaluated using Spearman correlation tests.

\section{RESULTS}

\section{Plasma Mineral Concentrations}

Plasma $\mathrm{Cu}$ concentrations changed differently over time in the 2 breed types (breed type $\times$ week interaction; $P<0.001$; Fig. 1), with concentrations in crossbred heifers decreasing more dramatically than in zebu heifers. Overall, plasma $\mathrm{Cu}$ concentrations decreased throughout the trial (week; $P<0.001$ ). Plasma concentrations of both $\mathrm{Fe}$ and Mo were not affected by breed type (breed type $\times$ week; $P=0.8, P=$ 0.3 , respectively). Over time, plasma Mo increased (week; $P=0.04$ ), whereas plasma Fe concentrations decreased (week; $P<0.001$ ).

Plasma $\mathrm{Zn}$ concentrations changed differently over time between the 2 breed types (breed type $\times$ week; $P=$ $0.04)$. However, unlike in the case of $\mathrm{Cu}$, plasma $\mathrm{Zn}$ concentrations seemed to differ between breed types at the start of the trial with a diminishing difference throughout the trial. Overall, plasma Zn concentrations were also affected by a breed type effect (breed type; $P=0.001$ ), with lower concentrations in crossbreeds than in zebu heifers throughout the trial. Over time, plasma $\mathrm{Zn}$ concentrations decreased (week; $P<0.001$ ).

Plasma Mn concentrations were not affected by breed type (breed type $\times$ week; all $P=0.3$ ) but tended to decrease slightly over time (week; $P=0.05$ ). Throughout the trial, plasma Se concentrations increased (week; $P<0.001$ ) but did not differ between breed types (breed type $\times$ week; $P=0.2$ ). Over time, plasma Co concentrations changed differently in both breed types (breed type $\times$ week; $P=0.001$ ), where the difference between breed types seemed large at the onset of the trial but afterward a smaller difference remained constant over time. Plasma Co concentrations were also subjected to an overall breed effect throughout the trial (breed type; $P<0.001$ ). Again, concentrations in crossbreeds were lower than in zebu heifers. Throughout the trial, plasma Co concentrations decreased (week; $P<0.001$ ).

\section{Tissue Mineral Concentrations}

The relative $\mathrm{Cu}$ tissue concentrations in the different organs tended to be different in the 2 breed types (breed type $\times$ tissue interaction; $P=0.06$; Fig. 2). Liver $\mathrm{Cu}$ concentrations were greater in zebu than in crossbred heifers $(P=0.002)$. No differences were found for other tissues (cardiac muscle, $P=1.0$, and kidney and semitendinsosus muscle, $P=0.9$ ). Relative tissue Mo concentrations were not impacted by breed type (breed type $\times$ tissue; $P=1.0$ ). On the contrary, relative tissue concentrations of Fe were different in the 2 breed types 


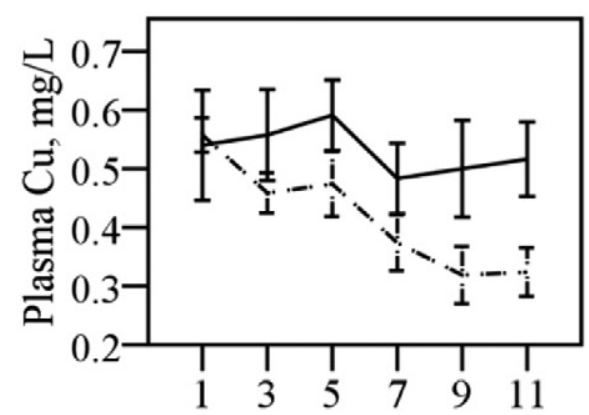

Experimental week

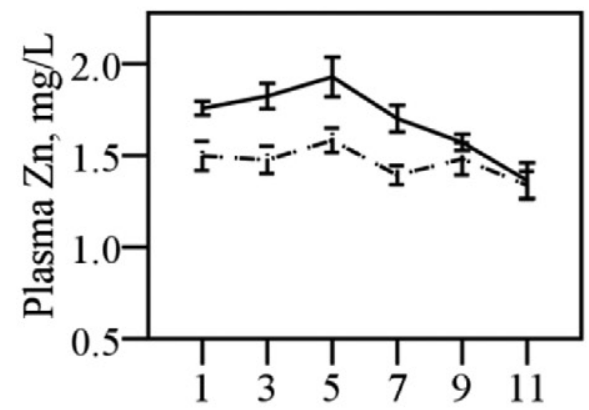

Experimental week

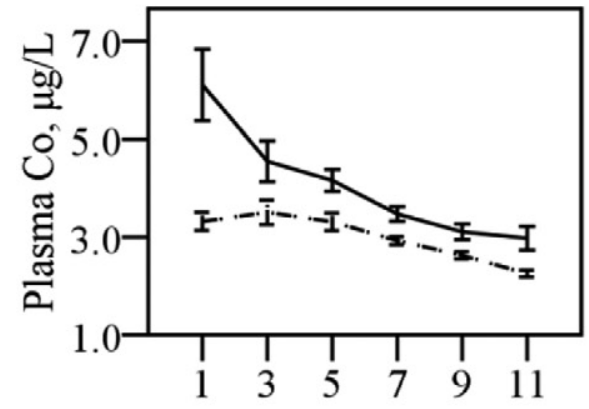

Experimental week

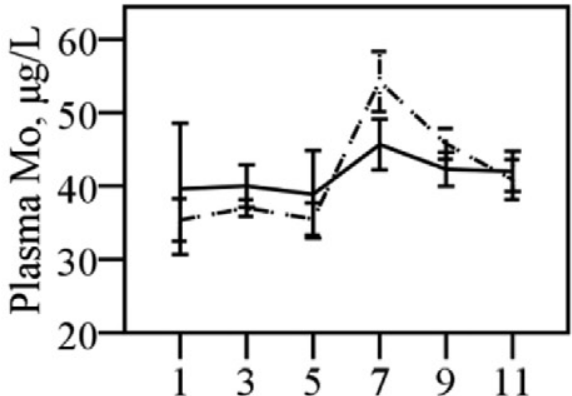

Experimental week

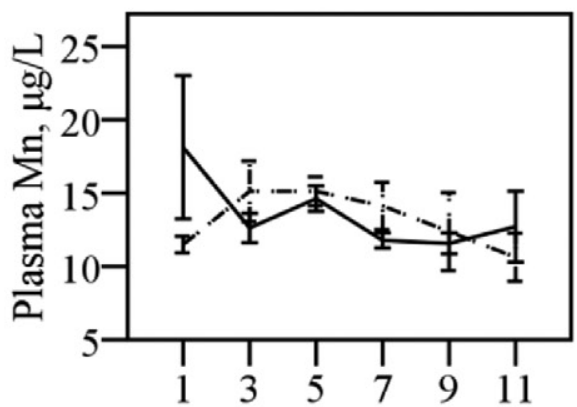

Experimental week

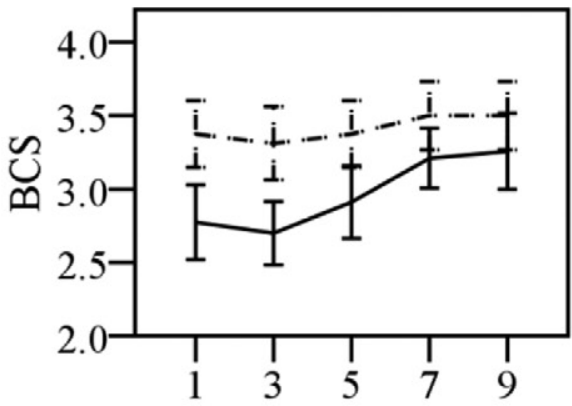

Experimental week

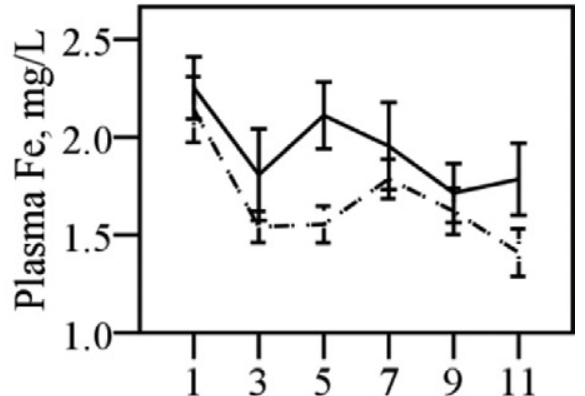

Experimental week

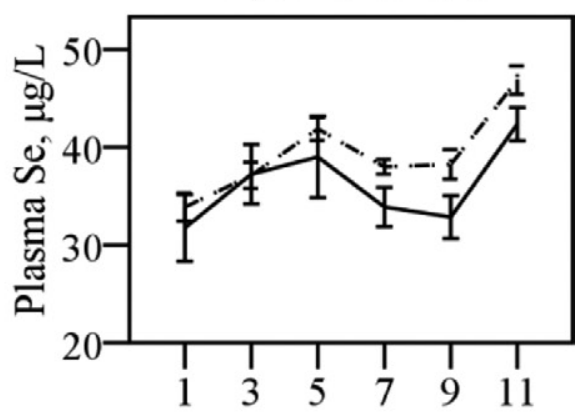

Experimental week

Figure 1. Plasma mineral concentrations and BCS in zebu (Bos indicus; $n=8)$ and crossbreed (Bos indicus $\times$ Bos taurus; $n=8)$ heifers on a Cu-deficient diet. Full lines represent zebu (Bos indicus) heifers, dotted lines represent crossed (Bos indicus $\times$ Bos taurus) heifers. Error bars represent \pm SEM. There was a significant breed type $\times$ week interaction for $\mathrm{Zn}, \mathrm{Cu}, \mathrm{Co}$, and $\mathrm{BCS}(P<0.05)$, significant breed type effect for $\mathrm{Zn}$ and $\mathrm{Co}(P<0.05)$, and significant time effect for all $(P<0.05)$ and a trend for $\operatorname{Mn}(P=0.05)$

(breed type $\times$ tissue; $P=0.01$ ): Iron liver concentrations were greater in zebu than in crossbreed cattle $(P<$ 0.001 ); other tissues were not impacted (cardiac muscle, $P=0.9$; kidney, $P=0.7$; and semitendinosus muscle, $P=1.0$ ). For $\mathrm{Zn}$ and $\mathrm{Mn}$ concentrations, no differences in tissue concentrations were found between the 2 types of cattle (breed type $\times$ tissue; $\mathrm{Zn}, P=0.6$, and $\mathrm{Mn}, P=$ $0.4)$. Relative tissue Se concentrations differed in the 2 breed types (breed type $\times$ tissue; $P<0.001$ ): zebu kidney Se concentrations were greater than crossbreed kidney Se concentrations $(P<0.001)$, but no differences were found for other tissues (cardiac and semitendinosus muscle, $P=0.7$, and liver, $P=0.4$ ). Finally, relative tissue Co concentrations were also affected by breed type (breed type $\times$ tissue; $P<0.001$ ) and both cardiac muscle and kidney Co concentrations were greater in zebu than in crossbreed heifers $(P<0.001)$.

\section{Tissue Gene Expression}

For $\mathrm{Cu}$ regulatory genes, no significant type differences in relative expression of duodenal Mtla mRNA were found ( $P=0.2$; Table 3$)$. However, hepatic mRNA expression of $\mathrm{Cu}$ regulatory genes $\operatorname{Ctrl}(P=0.025)$, Cox17 $(P=0.009), \operatorname{Atp} 7 b(P=0.022)$, and CCS $(P=$ $0.029)$ as well as $\operatorname{Sodl}(P=0.001)$ were greater in zebu than in crossbred cattle. Relative mRNA expression of genes related to $\mathrm{Cu}$ function, duodenal $D A O$, and aorta $L O X$ were not affected by type $(P=0.8)$. Breed type did affect relative mRNA expression of the Se-related Gpx1 in liver $(P<0.001)$.

Relative mRNA expression of Mt1a and CCS were correlated with liver $\mathrm{Cu}$ concentrations, whereas liver $\mathrm{Mo}$, Co and $\mathrm{Mn}$ concentrations were related to duodenal $D A O$ mRNA expression. Kidney Se concentrations were positively associated with liver mRNA expression 

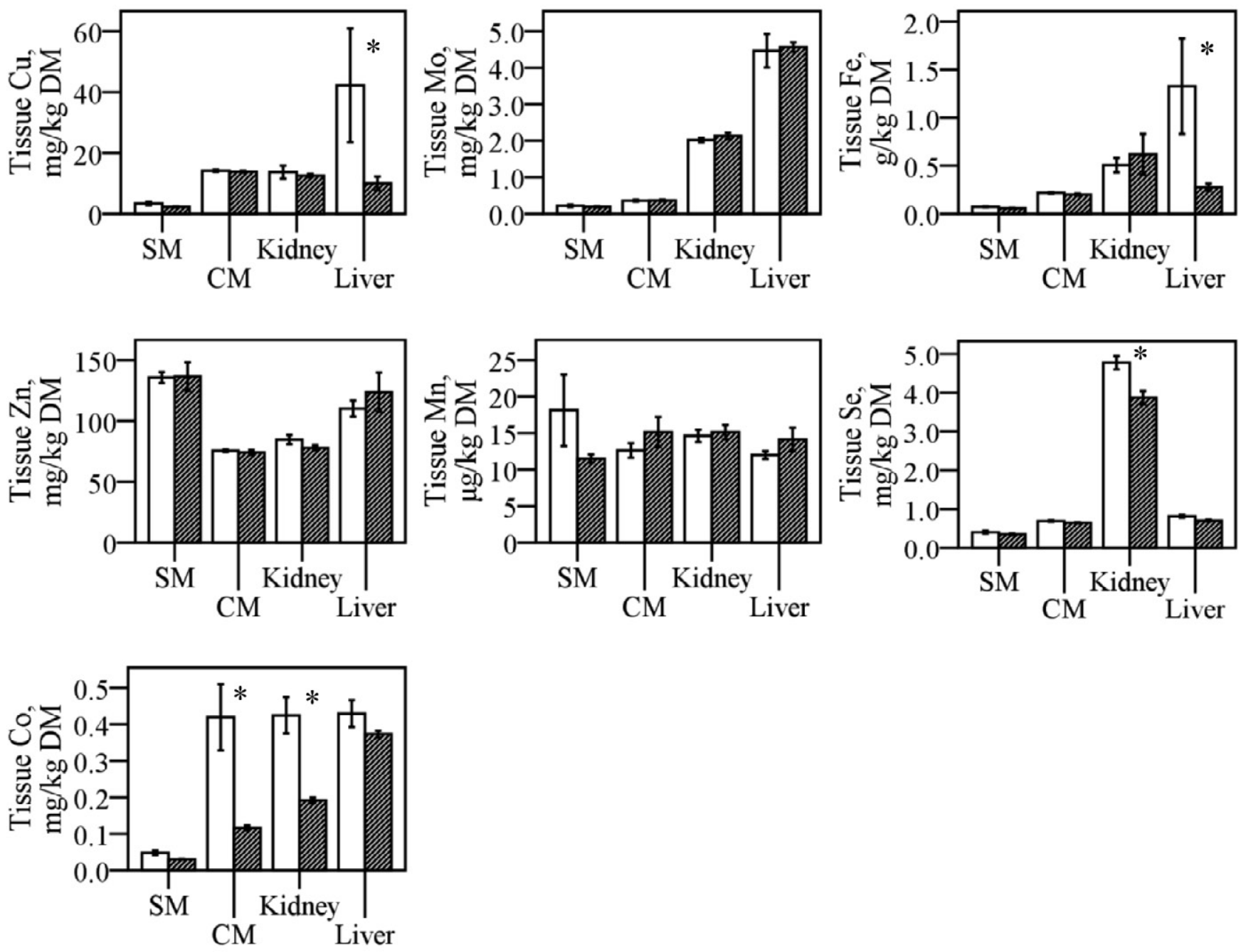

Figure 2. Tissue ( $\mathrm{SM}=$ semitendinosus muscle, $\mathrm{CM}=$ cardiac muscle, trace element concentrations in zebu (Bos indicus; $n=8)$ and crossbreed (Bos indicus $\times$ Bos taurus; $n=8$ ) heifers on a Cu-deficient diet. Clear bars represent zebu (Bos indicus) heifers. Dark bars represent crossbreed (Bos indicus $\times$ Bos taurus) heifers. Error bars represent \pm SEM. Asterisks represent significant difference in tissue trace element concentrations between breed types of cattle $(P<0.05$.

of Atp7b, CCS, Cox17, Ctr1, Sod1, and Gpxl (all $r>0.5$; all $P<0.050$; Table 4).

\section{Performance}

Initial BW was lower in zebu than in crosses $(91 \pm 5.3$ vs. $139 \pm 12.9 \mathrm{~kg} ; P=0.004)$. Initial BCS did not differ between breed types; on average, crossed heifers had an initial BCS of $3.4 \pm 0.23$ whereas on average, zebu heifers had an initial BCS of $2.8 \pm 0.25$ on a scale of 1 to $5(P=0.1)$.

Average daily gain was similar for both breed types $(P=0.3)$, but when expressed as percentage of initial BW, zebu gained more than crosses $(P=0.014)$, although the latter displayed a greater absolute DMI $(P=0.009)$ but not as percentage of BW $(P=0.433)$. Concomitantly, G:F was greater in zebu than in crosses $(P=0.014$; Table 5$)$. The BCS also evolved more positively for zebu than for crossbreeds (breed type $\times$ week interaction; $P=0.006$; Fig. 1).

\section{DISCUSSION}

In the present study, zebu and crossbred cattle were kept on a Cu-deficient diet supplemented with Mo over 11 wk to investigate the effect on plasma and tissue $\mathrm{Cu}$ and other trace elements and related mRNA expression. With the given dietary Mo and S concentrations and supplemented Mo, at the onset of the trial, the calculated absorption of $\mathrm{Cu}\left(\mathbf{A}_{\mathbf{C u})}\right.$ of the unsupplemented diet, using the formula of Suttle (1983) for grass diets, $\mathrm{A}_{\mathrm{Cu}}=5.7-1.3$ $\mathrm{S}-2.785 \log _{\mathrm{e}} \mathrm{Mo}+0.227(\mathrm{Mo} \times \mathrm{S})$, was $3.0 \%$, whereas when supplemented with $1 \mathrm{mg} / \mathrm{kg} \mathrm{Mo}, \mathrm{A}_{\mathrm{Cu}}$ dropped to $1.8 \%$, and when supplementation was raised to $2 \mathrm{mg} / \mathrm{kg}$ $\mathrm{Mo}, \mathrm{A}_{\mathrm{Cu}}$ finally decreased to $0.7 \%$. These values in combination with the low dietary $\mathrm{Cu}$ concentrations inevitably lead to a very low $\mathrm{Cu}$ uptake from the diet, with rapidly depleting reserves in the body as a consequence. Dietary $\mathrm{Cu}$ forms complexes with sulfides and thiomolybdates (by interaction with $\mathrm{Mo}$ and $\mathrm{S}$ ), thus rendering $\mathrm{Cu}$ unabsorbable. The thiomolybdates could also have been absorbed 
Table 3. Relative mRNA expression of trace element related genes in tissues harvested from zebu (Bos indicus; $n=8$ ) and crossbreed (Bos indicus $\times$ Bos taurus; $n=8$ ) heifers on a Cu-deficient $\operatorname{diet}^{1}$

\begin{tabular}{|c|c|c|c|c|c|}
\hline Tissue & Gene & Zebu & Crossbreed & SEM & $P$-value \\
\hline \multicolumn{6}{|c|}{$\mathrm{Cu}$ regulatory genes } \\
\hline Duodenum & Mt1a & 29 & 8 & 8.2 & 0.23 \\
\hline \multirow[t]{5}{*}{ Liver } & Ctrl & 3.7 & 2.0 & 0.39 & 0.03 \\
\hline & $C C S$ & 5.0 & 2.6 & 0.57 & 0.03 \\
\hline & Cox17 & 2.5 & 1.5 & 0.20 & 0.01 \\
\hline & Sodl & 3.4 & 1.6 & 0.31 & 0.001 \\
\hline & $A t p 7 b$ & 1.9 & 1.3 & 0.14 & 0.02 \\
\hline \multicolumn{6}{|c|}{$\mathrm{Cu}$-related genes } \\
\hline Aorta & $L O X$ & 2.5 & 2.4 & 0.29 & 0.84 \\
\hline Duodenum & $D A O$ & 9.1 & 10.3 & 1.89 & 0.77 \\
\hline \multicolumn{6}{|l|}{ Se-related gene } \\
\hline Liver & Gpxl & 3.0 & 1.5 & 0.24 & $<0.001$ \\
\hline
\end{tabular}

${ }^{1}$ Values are the mean relative copy number for the group.

through the ruminal wall, thereafter systemically binding $\mathrm{Cu}$ and causing a real thiomolybdate toxicity rather than a $\mathrm{Cu}$ deficiency (Gould and Kendall, 2011). However, the depletion of $\mathrm{Cu}$ reserves was reflected in the decreasing plasma $\mathrm{Cu}$ concentrations over time and low liver $\mathrm{Cu}$ concentrations at the end of the trial (overall mean $=26$ $\mathrm{mg} \mathrm{Cu} / \mathrm{kg} \mathrm{DM}$ ). The Mo concentrations in plasma, on the other hand, were slightly increased over time as seen by Ivan and Veira (1985); although most of the Mo will be excreted in the form of the thiomolybdates, some may also be absorbed as $\mathrm{MoO}_{4}$ (Ferguson et al., 1943). Concerning $\mathrm{S}$, unfortunately, there is still no practical tool to evaluate the $\mathrm{S}$ status of cattle, as pointed out by Dermauw et al. (2012), and it was therefore not possible to investigate the evolution of this status over time.

Overall, a $\mathrm{Cu}$ deficiency caused by Mo and $\mathrm{S}$ interaction was evident. However, the response to the causative diet differed distinctly between the 2 breed types of cattle. Although plasma $\mathrm{Cu}$ concentrations were quite similar at the onset of the trial, over time they slowly decreased in $B$. indicus cattle to concentrations just be- low the threshold value for deficiency in $B$. taurus cattle $(<0.57 \mathrm{mg} \mathrm{Cu} / \mathrm{L}$; Suttle, 2010), whereas B. taurus $\times B$. indicus crosses developed extremely low plasma $\mathrm{Cu}$ concentrations. Furthermore, liver $\mathrm{Cu}$ concentrations were greater, yet also more variable, in zebu than in crossbred cattle (42 vs. $10 \mathrm{mg} \mathrm{Cu} / \mathrm{kg} \mathrm{DM}$ ), $19 \mathrm{mg} \mathrm{Cu} / \mathrm{kg}$ DM being the threshold for deficiency in B. taurus cattle (Suttle, 2010). Seemingly, crosses were more prone to $\mathrm{Cu}$ deficiency than zebu cattle. Miranda et al. (2010) suggested 4 different reasons for differences between cattle breeds in sensitivity towards $\mathrm{Cu}$ deficiency: differences in efficiency of absorption, differences in distribution among tissues, differences in excretion, or differences in feed intake. Concerning the latter, in the present study, we saw a similar DMI (\% of BW) accompanied by a lower weight gain (\% initial weight) in crossbred cattle. Therefore, the hypothesis of a greater feed intake does not seem to match with the results of our study.

Previous studies of breed sensitivity to $\mathrm{Cu}$ deficiency found differences between Angus and Simmental cattle, with much lower plasma $\mathrm{Cu}$ concentrations in Simmental cattle (Smart and Christensen, 1985). This was further investigated by Gooneratne et al. (1994), who found that Simmental cattle had a much greater biliary excretion of $\mathrm{Cu}$. In the current study, we did not investigate differences in $\mathrm{Cu}$ excretion. Ward et al. (1995) showed that the Simmental breed seemed to have a lower apparent $\mathrm{Cu}$ absorption and $\mathrm{Cu}$ retention. Subsequently, Hansen et al. (2009) detected that $\mathrm{Cu}$ deficiency reduced mRNA expression of hepatic Sod1, whereas Fry et al. (2009) found decreased mRNA expression of Cox 17 and Atp $7 b$ and Hepburn et al. (2009) increased expression of CCS mRNA in Cu-deficient cattle. Fry et al. (2013) investigated differences in expression of $\mathrm{Cu}$ chaperones and transporters between Angus and Simmental cattle and detected a lower expression of duodenal copper transporters Ctrl and tendency for less Atp $7 a$ in Simmental cattle, suggesting a lower ability in these cattle to absorb and utilize dietary $\mathrm{Cu}$. However, they did not detect differences in hepatic mRNA expression levels.

Table 4. Correlation coefficients between trace element storage and relative mRNA expression of trace element related genes in tissues harvested from zebu (Bos indicus; $n=8)$ and crossbreed (Bos indicus $\times$ Bos taurus; $n=8)$ heifers on a Cu-deficient diet

\begin{tabular}{|c|c|c|c|c|c|c|c|c|c|}
\hline \multirow[b]{2}{*}{ Parameter } & \multirow{2}{*}{$\begin{array}{c}\text { Aorta } \\
L O X\end{array}$} & \multicolumn{2}{|c|}{ Intestine } & \multicolumn{6}{|c|}{ Liver } \\
\hline & & $D A O$ & Mt1a & $A t p 7 b$ & $C C S$ & $\operatorname{Cox} 17$ & Ctrl & Sod1 & Gpx1 \\
\hline Liver $\mathrm{Cu}$ & 0.12 & 0.38 & $0.60 *$ & 0.07 & $0.58 *$ & 0.17 & -0.13 & 0.15 & 0.22 \\
\hline Liver Mo & -0.27 & $0.65 * *$ & -0.21 & -0.26 & -0.29 & -0.39 & -0.32 & -0.28 & -0.33 \\
\hline Liver Fe & -0.06 & 0.33 & 0.15 & 0.36 & 0.23 & 0.13 & 0.15 & 0.28 & 0.33 \\
\hline Liver Mn & 0.01 & $0.58 *$ & 0.03 & 0.09 & 0.17 & 0.06 & 0.01 & 0.23 & 0.17 \\
\hline Liver Zn & -0.06 & -0.26 & 0.02 & -0.07 & -0.12 & -0.10 & -0.06 & -0.15 & -0.17 \\
\hline Kidney Se & 0.22 & -0.09 & -0.20 & $0.57 *$ & $0.64 * *$ & $0.55^{*}$ & $0.59^{*}$ & $0.73 * *$ & $0.84 * *$ \\
\hline Liver Co & 0.09 & $0.53 *$ & 0.43 & 0.25 & 0.26 & 0.29 & 0.27 & 0.39 & 0.28 \\
\hline
\end{tabular}

$* P<0.05 ; * * P<0.01$. 
In our study, where the induced $\mathrm{Cu}$ deficiency was more severe than in the study of Fry et al. (2013), zebu cattle seemed to have greater relative expression of the hepatic $\mathrm{Cu}$ transporters and chaperones CCS, Ctrl, Cox 17, Sod1, and Atp $7 b$ mRNA. We did not investigate the intestinal expression of these genes, but zebu and crossbred cattle may also differ in expression of intestinal $\mathrm{Cu}$ transporters and chaperones, which could point to better absorption mechanisms in zebu vs. crossbred cattle, with greater liver and plasma $\mathrm{Cu}$ levels as a consequence. Although high variability in Mt1a mRNA expression did not allow discerning the potential differences between breed types, the positive correlation with liver $\mathrm{Cu}$ concentrations does point in this direction. Further research is necessary to confirm this. The expression of CCS was also positively associated with liver $\mathrm{Cu}$, in contradiction with earlier data from Han et al. (2009). At this point, we could hypothesize that the greater expression of the hepatic $\mathrm{Cu}$ transporters and chaperones suggest that the zebu cattle have a greater $\mathrm{Cu}$ uptake in hepatocyte (Ctrl), combined with a greater $\mathrm{Cu}$ circulation $(C C S)$ and incorporation in ceruloplasmin (Atp 7b), and cytochrome c oxidase (Cox 17), used for scavenging of superoxide ions ( $\operatorname{Sod} 1)$ within the hepatocyte as well as greater $\mathrm{Cu}$ excretion from the hepatocyte $(A t p 7 b$; Prohaska, 2004; Fry et al., 2013).

An overload of $\mathrm{Fe}$ can exacerbate a $\mathrm{Cu}$ deficiency, through exchanges of $\mathrm{Fe}$ sulfides with $\mathrm{Cu}$ to unabsorbable $\mathrm{Cu}$ sulfides or through formation of an equally insoluble Fe-Cu-S complex (Gould and Kendall, 2011). In the present study, $\mathrm{Fe}$ concentrations in the diet were not as high as previously found values in grasses in the same region (619 to $2,082 \mathrm{mg} \mathrm{Fe} / \mathrm{kg} \mathrm{DM}$; Dermauw et al., 2013b), and the critical dietary $\mathrm{Fe}: \mathrm{Cu}$ ratio was not reached (50 to 100; Suttle, 2010), so an additive effect of $\mathrm{Fe}$ on the $\mathrm{Cu}$ deficiency was not to be expected. On the contrary, the $\mathrm{Cu}$ deficiency seemed to have affected the Fe metabolism, which was reflected in our study by decreasing, but not deficient, plasma Fe concentrations over time and high liver Fe concentrations (overall mean $=801$ mg Fe/kg DM). Hansen et al. (2010, p. 280) postulated that "Limited ceruloplasmin activity probably prevented $\mathrm{Fe}$ from being mobilized out of the liver, causing Fe to accumulate in the liver and limiting Fe availability for extrahepatic tissues," which may explain the decreasing plasma Fe concentrations noted in our study. The evolution of plasma Fe concentration over time did not differ between the 2 breed types of cattle. However, zebu cattle did have more variable and greater liver Fe concentrations than crossbred cattle, which were also greater than found in previous research in the area (Dermauw et al., 2013a). Although this difference seems to contradict the ceruloplasmin explanation of Hansen et al. (2010), dietary $\mathrm{Cu}$ levels were lower than in the supplemented study group of Hansen et al. (2010), and therefore, the range in $\mathrm{Cu}$
Table 5. Performance in zebu (Bos indicus; $n=8$ ) and crossbreed (Bos indicus $\times$ Bos taurus; $n=8$ ) heifers on a $\mathrm{Cu}$-deficient diet

\begin{tabular}{lcccc}
\hline \hline Parameter & Zebu & Crossbreed & SEM & $P$-value \\
\hline Final BW, kg & 103 & 148 & 9.4 & 0.01 \\
ADG, kg & 0.16 & 0.12 & 0.018 & 0.32 \\
DMI, kg/d & 1.92 & 2.82 & 0.184 & 0.01 \\
G:F & 0.08 & 0.04 & 0.009 & 0.01 \\
DMI, \% BW & 1.98 & 1.98 & 0.003 & 0.51 \\
Total gain, \% initial BW & 13 & 6.0 & 1.48 & 0.01 \\
\hline
\end{tabular}

status is much smaller in our study. Nevertheless, the extremely high liver Fe concentrations in zebu cattle were striking and further research is warranted to determine the physiological reasons for this.

In the current study, zebu cattle had greater kidney Se concentrations than crosses and Gpx-1 mRNA expression was greater in zebu than in crosses, but no breed type $\times$ week interaction affected plasma Se concentrations. Langlands et al. (1980) previously found greater whole blood Se and Gpx1-Se activity in B. indicus (Afrikaander) than in B. taurus (Hereford-Shorthorn) cattle, with crosses having intermediate values. We know of no other studies investigating breed differences in bovine blood Se status or in kidney Se concentrations or Gpx 1 mRNA expression. We do know that $\mathrm{Cu}$ and Se metabolism are interrelated, with lower Gpx1 activity and Gpx1 mRNA expression and greater fecal excretion of $\mathrm{Se}$ in $\mathrm{Cu}$-deficient rats (Jenkinson et al., 1982; Olin et al., 1994). In this respect, the seemingly lower ability in crosses to cope with this $\mathrm{Cu}$ deficiency might have caused the lower mRNA expression of Gpxl. The positive association of Se storage and mRNA expression of $\mathrm{Cu}$ regulatory genes, Ctr 1, CCS, Atp 7b, Cox 17, and Sod1, suggests shared pathways between $\mathrm{Cu}$ and Se yet to be elucidated. Overall, Se concentrations increased throughout the trial, which contradict the greater fecal excretion in $\mathrm{Cu}$ deficiency, but the rise, although significantly different over time, is small and may not be relevant. Finally, the differences between cattle breed types in plasma Co and semitendinosus muscle and kidney Co concentrations may be irrespective of the $\mathrm{Cu}$ deficiency but warrant further research on differences in trace element metabolism between $B$. indicus and $B$. taurus breed types of cattle.

In conclusion, $B$. indicus and $B$. taurus $\times B$. indicus cattle had a disparate response to a $\mathrm{Cu}$-deficient diet supplemented with Mo. Concentrations of $\mathrm{Cu}$, both in transport and storage pools, were greater in $B$. indicus cattle than in crossbred cattle. In $B$. indicus cattle, this coincided with a greater mRNA expression of $\mathrm{Cu}$ regulatory and related genes in the liver. This may suggest a more efficient use of dietary $\mathrm{Cu}$ in $\mathrm{B}$. indicus and a lower proneness to $\mathrm{Cu}$ deficiency in comparison with $B$. taurus $\times B$. indicus 
cattle. In $B$. indicus cattle, concentrations of $\mathrm{Zn}$ and $\mathrm{Co}$ in the transport pool and concentrations of $\mathrm{Fe}, \mathrm{Se}$, and Co in certain storage pools as well as a hepatic mRNA expression of the Se-related Gpxl were also observed to be greater. Overall, future research is warranted to fully unravel these potential differences in trace element metabolism between $B$. indicus and B. taurus $\times B$. indicus cattle and to investigate to which extent such differences may also translate in different trace element requirements in the 2 breed types.

\section{LITERATURE CITED}

AOAC. 2000. Official methods of analysis. 17th ed. AOAC Int., Arlington, VA.

Damir, A., M. E. S. Barri, S. El Hassan, M. Tageldin, A. Wahbi, and O. Idris. 1988. Clinical zinc and copper deficiencies in cattle of Western Sudan. Trop. Anim. Health Prod. 20:52-56.

Dermauw, V., E. Froidmont, J. Dijkstra, J. De Boever, W. Vyverman, A.-E. Debeer, and G. P. J. Janssens. 2012. Sulphur levels in saliva as an estimation of sulphur status in cattle: A validation study. Arch. Anim. Nutr. 66:507-513.

Dermauw, V., K. Yisehak, D. Belay, T. Van Hecke, G. Du Laing, L. Duchateau, and G. P. J. Janssens. 2013a. Mineral deficiency status of ranging zebu (Bos indicus) cattle around the Gilgel Gibe catchment, Ethiopia. Trop. Anim. Health Prod. 45:1139-1147.

Dermauw, V., K. Yisehak, E. S. Dierenfeld, G. Du Laing, J. Buyse, B. Wuyts, and G. P. J. Janssens. 2013b. Effects of trace element supplementation on apparent nutrient digestibility and utilisation in grass-fed zebu (Bos indicus) cattle. Livest. Sci. 155:255-261.

Edea, Z., H. Dadi, S.-W. Kim, T. Dessie, T. Lee, H. Kim, J.-J. Kim, and K.-S. Kim. 2013. Genetic diversity, population structure and relationships in indigenous cattle populations of Ethiopia and Korean Hanwoo breeds using SNP markers. Front. Genet. 4:1-9.

Faye, B., and C. Grillet. 1984. Copper deficiency in domestic ruminants in the Awash region (Ethiopia). I. Plasmatic copper and ceruloplasmin content in sheep, goats, cattle and camels of the Awash region (Ethiopia). Rev. Elev. Med. Vet. Pays Trop. 37:42-60.

Faye, B., C. Grillet, A. Tessema, and M. Kamil. 1991. Copper deficiency in ruminants in the Rift Valley of East Africa. Trop. Anim. Health Prod. 23:172-180.

Fekadu, A., T. Kassa, and K. Belehu. 2011. Study on reproductive performance of Holstein-Friesian dairy cows at Alage Dairy Farm, Rift Valley of Ethiopia. Trop. Anim. Health Prod. 43:581-586.

Ferguson, W., A. Lewis, and S. Watson. 1943. The teart pastures of Somerset: I. The cause and cure of teartness. J. Agric. Res. 33:44-51.

Friot, D. 1973. Biochimie et élévage au Sénégal. (In French.) Rev. Elev. Med. Vet. Pays Trop. 26:75-98.

Fry, R. S., M. S. Ashwell, S. L. Hansen, T. Engle, H. Han, and J. W. Spears. 2009. Effects of copper deficiency on gene expression profiles of copper transporters and chaperones in steers. J. Anim. Sci. 87(Suppl. 2):561 (Abstr.).

Fry, R. S., J. W. Spears, K. E. Lloyd, A. T. O’Nan, and M. S. Ashwell. 2013. Effect of dietary copper and breed on gene products involved in copper acquisition, distribution, and utilization in Angus and Simmental cows and fetuses. J. Anim. Sci. 91:861-871.

Gooneratne, S., H. Symonds, J. Bailey, and D. Christensen. 1994. Effects of dietary copper, molybdenum and sulfur on biliary copper and zinc excretion in Simmental and Angus cattle. Can. J. Anim. Sci. 74:315-325.

Gould, L., and N. R. Kendall. 2011. Role of the rumen in copper and thiomolybdate absorption. Nutr. Res. Rev. 24:176-182.
Han, H., S. L. Archibeque, and T. E. Engle. 2009. Characterization and identification of hepatic mRNA related to copper metabolism and homeostasis in cattle. Biol. Trace Elem. Res. 129:130-136.

Hansen, S. L., M. S. Ashwell, L. R. Legleiter, R. S. Fry, K. E. Lloyd, and J. W. Spears. 2009. The addition of high manganese to a copper-deficient diet further depresses copper status and growth of cattle. Br. J. Nutr. 101:1068-1078.

Hansen, S. L., N. Trakooljul, H. C. Liu, J. A. Hicks, M. S. Ashwell, and J. W. Spears. 2010. Proteins involved in iron metabolism in beef cattle are affected by copper deficiency in combination with high dietary manganese, but not by copper deficiency alone. J. Anim. Sci. 88:275-283.

Haque, I., E. Aduayi, and S. Sibanda. 1993. Copper in soils, plants, and ruminant animal nutrition with special reference to subSaharan Africa. J. Plant Nutr. 16:2149-2212.

Hepburn, J. J., J. D. Arthington, S. L. Hansen, J. W. Spears, and M. D. Knutson. 2009. Technical note: Copper chaperone for copper, zinc superoxide dismutase: A potential biomarker for copper status in cattle. J. Anim. Sci. 87:4161-4166.

Ivan, M., and D. M. Veira. 1985. Effects of copper sulfate supplement on growth, tissue concentration, and ruminal solubilities of molybdenum and copper in sheep fed low and high molybdenum diets. J. Dairy Sci. 68:891-896.

Jenkinson, S. G., R. A. Lawrence, R. F. Burk, and D. M. Williams. 1982. Effects of copper deficiency on the activity of the selenoenzyme glutathione peroxidase and on excretion and tissue retention of 75SeO3(2-). J. Nutr. 112:197-204.

Langlands, J., J. Bowles, G. Donald, T. Ch'ang, R. Evans, H. Hearnshaw, and T. Post. 1980. Genotype as a source of variation in selenium concentration and glutathione peroxidase activity of whole blood from grazing sheep and cattle. Aust. J. Agric. Res. 31:839-848.

McDowell, L. R. 1996. Feeding minerals to cattle on pasture. Anim. Feed Sci. Technol. 60:247-271.

McDowell, L. R., and J. D. Arthington. 2005. Minerals for grazing ruminants in tropical regions. 4th ed. Univ. of Florida, Institute of Food and Agricultural Sciences, Gainesville, FL.

Miranda, M., B. Gutiérrez, J. L. Benedito, I. Blanco-Penedo, M. García-Vaquero, and M. López-Alonso. 2010. Influence of breed on blood and tissue copper status in growing and finishing steers fed diets supplemented with copper. Arch. Anim. Nutr. 64:98-110.

Mullis, L., J. Spears, and R. McCraw. 2003. Effects of breed (Angus vs Simmental) and copper and zinc source on mineral status of steers fed high dietary iron. J. Anim. Sci. 81:318-322.

Nicholson, M. J., and M. H. Butterworth. 1986. A guide to condition scoring of zebu cattle. International Livestock Centre for Africa, Addis Ababa, Ethiopia.

Olin, K., R. Walter, and C. Keen. 1994. Copper deficiency affects selenoglutathione peroxidase and selenodeiodinase activities and antioxidant defense in weanling rats. Am. J. Clin. Nutr. 59:654-658.

Peters, I. R., C. R. Helps, E. J. Hall, and M. J. Day. 2004. Real-time RT-PCR: Considerations for efficient and sensitive assay design. J. Immunol. Methods 286:203-217.

Prohaska, J. 2004. Intracellular copper transport in mammals. J. Nutr. 134:1003-1006.

Roeder, P. 1980. Effects of copper and cobalt treatment of cattle in the Ethiopian Rift Valley. Trop. Anim. Health Prod. 12:63-68.

Rozen, S., and H. Skaletsky. 2000. Primer3 on the WWW for general users and for biologist programmers. In: S. Krawetz and S. Misener, editors, Bioinformatics methods and protocols: Methods in molecular biology. Humana Press, Totowa, NJ. p. 365-386.

SantaLucia, J., Jr. 1998. A unified view of polymer, dumbbell, and oligonucleotide DNA nearest-neighbor thermodynamics. Proc. Natl. Acad. Sci. U.S.A. 95:1460-1465. 
Smart, M. E., and D. A. Christensen. 1985. The effect of cow's dietary copper intake, sire breed, age on her copper status and that of her fetus in the first ninety days of gestation. Can. J. Comp. Med. 49:156-158.

Suttle, N. F. 1983. Effect of molybdenum concentration in fresh herbage, hay and semi-purified diets on the copper metabolism in sheep. J. Agric. Sci. 100:651-656.

Suttle, N. F. 2010. Mineral nutrition of livestock. 4th ed. CABI Publishing, Wallingford, Oxfordshire, UK.

Vandesompele, J., K. De Preter, F. Pattyn, B. Poppe, N. Van Roy, A. De Paepe, and F. Speleman. 2002. Accurate normalization of realtime quantitative RT-PCR data by geometric averaging of multiple internal control genes. Genome Biol. 3:RESEARCH0034.

Van Soest, P. J., J. B. Robertson, and B. A. Lewis. 1991. Methods for dietary fiber, neutral detergent fiber and nonstarch polysaccharides in relation to animal nutrition. J. Dairy Sci. 55:1275-1280.
Ward, J. D., J. W. Spears, and G. P. Gengelbach. 1995. Differences in copper status and copper metabolism among Angus, Simmental, and Charolais cattle. J. Anim. Sci. 73:571-577.

Wildman, E. E., G. M. Jones, P. E. Wagner, R. L. Boman, H. F. Troutt Jr., and T. N. Lesch. 1982. A dairy cow body condition scoring system and its relationship to selected production characteristics. J. Dairy Sci. 65:495-501.

Yisehak, K., A. Becker, J. M. Rothman, E. S. Dierenfeld, B. Marescau, G. Bosch, W. Hendriks, and G. P. J. Janssens. 2012. Amino acid profile of salivary proteins and plasmatic trace mineral response to dietary condensed tannins in free-ranging zebu cattle (Bos indicus) as a marker of habitat degradation. Livest. Sci. 144:275-280. 
References

This article cites 36 articles, 9 of which you can access for free at: http://www.journalofanimalscience.org/content/92/7/3007\#BIBL 